\title{
A Study on Modals Used in Text Your Say of The Jakarta Post
}

\author{
Elisabeth Rosalia Widyanti \\ Made Frida Yulia \\ English Language Education Study Program \\ Sanata Dharma University
}

\begin{abstract}
Communication happens not only in spoken form, but also in written form. Newspaper, as one form of written communication, provides ways for people to show their opinion, intention, and thought. In the way people communicate by using language, modals enable people to show something which is not simply positive or negative and each modal has some functions to show people's thought, intentions, or opinion.

This study dealt with how modals were used by the commentators in Text Your Say of The Jakarta Post. To solve the problem, the theories from Azar and Hagen (2009) and Leech and Svartvik (1994) were employed. The findings showed that there were 225 modals found in Text Your Say of The Jakarta Post issued in November 2012. They consisted of may, might, should, had better, be supposed to, must, have to, will, can, could, be able to, and would. They were used by the commentators to show some functions. The functions were to show $50 \%$ or less certainty, 90\% certainty, 95\% certainty, 100\% certainty, ability/possibility, past ability, impossibility, necessity, strong necessity, advisability, suggestion, prohibition, expectation, unfulfilled wish/hypothesis, willingness, polite for "want", and fulfilled future condition in the past.
\end{abstract}

Keywords: modals,comments, Text Your Say

\section{A. INTRODUCTION}

Communication involves two or more people and it is commonly done by using language. In communicating, people express their opinion, intention, and thought. Implicitly, people also show their attitude when they communicate with others by using language. It is clear that language really playsan important role in human's life. Lehmann (1983, p. 1) says that "language provides the means for us to take our place in society to express our wants and convey information, to learn about people and the world around us." Therefore, it is important to study "how people use language within a context and why they use language in particular ways" (McManis, Stollenwerk, \&Zheng-Sheng, 1987, p. 197).
The expressions of attitude and feeling of the speaker can be seen by the modality used. In expressing feeling and attitude, the language users will not only show something which is simply positive or negative. Sometimes they show possibility of something which is not clear whether it is right or not. Modality enables people to show the intermediate degree between yes and no (Halliday, 2004, p. 147). Using modal auxiliaries or modals is one of the ways to show modality. Phrasal modals can also semantically represent modals. Expressing modals and phrasal modals in the clause or sentence will allow the speaker to give the degree of possibility, certainty, politeness, and also directness (Celce-Murcia \& LarsenFreeman, 1999). 
Newspapers are media of information which people read. In Indonesia there are many newspaper companies. However, The Jakarta Post is the country's leading English language newspaper. The Jakarta Post also provides a place where the readers can show their opinions. The column is Reader's Forum, which contains many parts. One of its partsis Text Your Say. In Text Your Say readers can send a short message or email to comment on some issues which have been reported previously. The topic or issue is decided by the editorial staff of The Jakarta Post.

In commenting on issues, readers give their opinions about the issues. In expressing opinions, sometimes they use modals; for by using modals, they may express their degree of certainty, willingness, possibility, expectation or other things. In this study, how the modals were used in Text Your Say of The Jakarta Post issued in November 2012 was to be discussed. The discussionwould then be related to the functions that each modal performed.

\section{B. DISCUSSION}

The study was a document analysis. According to Ary et al. (2010, p. 457), document analysis is a research method applied to written or visual materials. The data analyzed were the comments in Text Your Say issued in November 2012. In total, there were 25 copies of The Jakarta Post,from which Text Your Say was taken.

From the analysis, 225 modals were found. The modals consisted of modal auxiliaries and phrasal modals. Modal auxiliaries generally express the attitude of the speakers (Azar \& Hagen, 2009, p. 157). Phrasal modal is also another form which functions semantically like true modals or modal auxiliaries (Celce-Murcia \& LarsenFreeman, 1999). Azar and Hagen (2009) explain that modals express what a speaker feels whether something is necessary, advisable, possible, permissible, or probable. Modals also convey the strength of those attitudes. In this section, the analyses of each modal found in the comments are presented. 1. May

May was used once in Text Your Say in November 2012. It appeared on November 8 , 2012. There was only one function expressed, i.e. expressing $50 \%$ or less certainty, as illustrated in [1].

[1] We may also hear more of Bahasa in the US which is a touchy subject. (November 8, 2012)

Azar and Hagen (2009, p. 204) propose that may can show less than $50 \%$ certainty, polite request and formal permission. In the sentence where may was found, it showed the certainty degree of the commentator of an issue. It was not classified as a polite request because a polite request is in the form of an interrogative, as Azar and Hagen (2009, p. 204) exemplify in "May I borrow your pen?" It was also not a formal permission because the commentator did not give any permission to us to hear more Bahasa in the US, but he showed the possibility of Bahasa to be heard more and in this sentence he gave his degree of certainty, which was $50 \%$ or less by using may.

\section{Might}

Azar and Hagen (2009) explain that might can be used to show less than $50 \%$ certainty and polite request. In November 2012 the commentators mentioned might four times. All might mentioned in the sentences functioned to show less than $50 \%$ certainty, as shown in [2].

[2] Romney, like any other Republican president, might seek Indonesia only when he needs to and not as partner. (November 8, 2012)

In this sentence, the commentator explained his thought of the possibility and stated his $50 \%$ certainty of the possibility.That 
sentence was not polite requests because the commentator did not ask for something and the sentence was not interrogative. In addition, Azar and Hagen (2009) state that it is rare to use might in showing polite request.

\section{Should}

Should was often used by the commentators of Text Your Say of The Jakarta Post. It was proven by thirty uses of should as what Table 1 showed. Azar and Hagen (2009) state that should is commonly used to express advisability. It also functions to show $90 \%$ certainty or expectation for the present, future and past meaning. In the comments using should, the commentators of Text Your Say showed advisability 26 times and 90\% certainty four times.

Advisability was shown in [3].In this case, the commentator showed the necessity of maintaining and implementing the spirit of unity. He also gave a suggestion to maintain and implement the spirit by using should.

[3] The spirit of unity echoed by young people across the country in 1928 should be maintained and implemented in the life of the nation. (November 1, 2012)

Table 1: The Occurrences of Should

\begin{tabular}{|c|c|}
\hline Function & Occurrences \\
\hline Advisability & 26 \\
\hline 90\% certainty (expectation) & 4 \\
\hline TOTAL & $\mathbf{3 0}$ \\
\hline
\end{tabular}

On the other hand, $90 \%$ certainty was shown in [4]. In the sentence the commentator believed that people would be grateful because of the sharp increase in Jakarta's minimum wage which was discussed at that time.

[4] They should be grateful. (November 24, 2012)

\section{Had Better}

Had better is a phrasal modalwhich is used to show advice and usually with threat of a bad result (Azar \& Hagen, 2009). In the comment which was mentioned in Text Your Say, had better appeared once on November 7 , 2012.

[5] Mr. Andi, you'd better resign voluntarily for the sake of your nation. (November 7, 2012)

Sentence [5] illustrated the use of had better to show advisability. The advice was related to the Hambalang scandal, implicating two ministers and causing Rp 243.6 billion in state losses. The commentator had an opinion and he expressedit in the form of an advice towards Mr. Andi to voluntarily resign.

\section{Be Supposed to}

Be supposed to was found once in Text Your Say in November 2012. Azar and Hagen (2009) propose that in the present or future form, be supposed to is used to show expectation and in the past form, it is used to show unfulfilled expectation. On November 17, a commentator wrote a comment using be supposed to. The one instance found in Text Your Say was presented in [6].

[6] If those requirements fail to be fulfilled, the government is supposed to recall Indonesian ambassador to Malaysia and at the same time, send the Malaysian ambassador home. (November 17, 2012)

In [6] be supposed to functioned as expectation. The sentence did not show unfulfilled expectation because it used present tense, 
whereas unfulfilled expectation requires past form of sentence (Azar \& Hagen, 2009).

\section{Must}

There were twenty occurrences of must found in November 2012 comments, as shown in Table 2. Azar and Hagen (2009) state that must shows strong necessity and 95\% certainty in the present and past forms. In showing necessity, it can also be used in the future time. It also expresses prohibition by making it negative but it is only for the future or present time (Azar \& Hagen, 2009, p. 204).

Table 2: The Occurrences of Must

\begin{tabular}{|c|c|}
\hline Function & Occurrences \\
\hline strong necessity & 14 \\
\hline prohibition (negative) & 1 \\
\hline 95\% certainty & 5 \\
\hline TOTAL & $\mathbf{2 0}$ \\
\hline
\end{tabular}

In Text Your Say of The Jakarta Post published in December 2012, there were twenty occurrences of must. Related to the functions, those twenty occurrences had three different functions of must. Fourteen occurrences were showing strong necessity, one occurrence was showing prohibition, and five occurrences were showing $95 \%$ certainty.

The first instance of the use of mustshowing strong necessity wasshown in [7].

[7] In addition to that, SBY must prove his commitment to fighting corruption by directly firing the two ministers concerned. (November 7, 2012)

In the sentence the commentator believed that it was very important for SBY to prove his commitment. The commentator gave a solution or a way to SBY in proving his commitment, which was firing the two ministers who were related to Hambalang scandal. The sentence was not in the negative form of must, so it was not showing prohibition. In addition, SBY had not fired the ministers to prove his commitment. Thus, it was not showing certainty either.

There was also one prohibition shown in the comments. Sentence [8] was the only comment appearing in Text Your Saywhich performed this function. Not became the signal of this function in this sentence.

[8] Unity must not be undermined by any interests, including those of tribes, religions or classes. (November 1, 2012)

The last function which was expressed by must in Text Your Say in November 2012 was $95 \%$ certainty. The commentators mentioned must which performed this function five times. Sentence [9]was one of the comments illustrating the function.

[9] Roki must now have more than one burqa, probably in different colors. (November 14, 2012)

In [9] the commentator was certain that Roki, the prisoner who had escaped, had many burqas because he escaped by using burqa trick. However, the joke or sarcasm was implied in this sentence.

\section{Have to}

One of the phrasal modals found was have to. There were sixteen occurrences of have to in the data. Have to is the counterpart of must(Celce-Murcia \& Larsen-Freeman, 1999). However, related to the function, have to has a difference. In positive form, have to functions to show necessity, like what must 
does. Despite this, in negative formhave to shows lack of necessity whereas the negative form of must shows prohibition (Azar \& Hagen, 2009, p. 204).

All the sentences showed necessity. The clear sign was the positiveform of have to used in the sentences, as illustrated in [10]. It expressed the importance or necessity to focus more on the fate of Iranian.

[10] They have to engage more on the fate of Iranians than nuclear talks. (November 9, 2012)

\section{Will}

Will was the most commonly used modal. Table 3 indicated that there were 67 occurrences of will in Text Your Say in November 2012. The use of will in the comments showed two of three functions proposed by Azar and Hagen (2009). The functions shown were $100 \%$ certainty and willingness. There was no one using will to show polite request.

Table 3: The Occurrences of Will

\begin{tabular}{|c|c|}
\hline Function & Occurrences \\
\hline $100 \%$ certainty & 49 \\
\hline Willingness & 18 \\
\hline polite request & 0 \\
\hline TOTAL & $\mathbf{6 7}$ \\
\hline
\end{tabular}

The example comment expressing $100 \%$ certainty was presented in [11]. It was a comment related to the presidential election in the US. The commentator expressed his thought that in the future he was sure that America still became an important country for Indonesia whether Barack Obama was elected or not.

[11] Whether Barack Obama is elected or not, the US will remain an important country for Indonesia. (November 8, 2012)

The remaining occurrences of will in the data expressed willingness. This function was revealed in eighteenoccurrences, one of whom was sentence [12].

[12] Whenever needed, he will always extend a helping hand to Indonesia. (November 8, 2012)

It was identified to be showing willingness because the subject of the sentence was willing to do something. Sentence [12] discussed what if Obama was reelected as the president. The commentator first said that if the heart was with Indonesia, the head followed. Because of that, in [12] the commentator said, whenever needed, he wanted to help Indonesia. In the sentence, the willingness belonged to the subject 'he.'

\subsubsection{Can}

Can was the modal which had forty occurrences in Text Your Say November 2012. Azar and Hagen (2009) state that can expresses ability or possibility, informal permission, informal polite request and impossibility by using the negative form of can. In the present or future time and in the past form, it only shows the ability or possibility and impossibility by using the negative form ( $p$. 205).

As seen in Table 4, can showed ability/ possibility and impossibility. There was no occurrence showing informal permission and informal request. There was one occurrence of can taken as an example of showing ability or possibility; it was presented in [13]. 
[13] The story of Othman can inspire the youth of Indonesia to take its opportunities. (November 1, 2012)

Sentence [13] stated that the story of Othman was able to show the youth of Indonesia to take the opportunities. Therefore, it expressed ability. The next example, sentence [14], expressed impossibilities. It explained that it was impossible for the mountain to block the sun. Therefore, the function of modal in such a sentence was classified into impossibility.

[14] No matter how tall the mountain (other countries) is, it cannot block the sun. (November 3, 2012)

Table 4: The Occurrences of Can

\begin{tabular}{|c|c|}
\hline Function & Occurrences \\
\hline ability/possibility & 33 \\
\hline informal permission & 0 \\
\hline informal polite request & 0 \\
\hline impossibility (negative) & 7 \\
\hline TOTAL & $\mathbf{4 0}$ \\
\hline
\end{tabular}

\section{Could}

There were 21 occurrences of could. There were several functions shown in the data as they were written in Table 5. Past ability was expressed twelve times; suggestion was expressed twice; $50 \%$ or less certainty was expressed five times; impossibility was expressed twice. However, there was no could used in the comments expressing a polite request.

Azar and Hagen mention that could shows past ability (Azar \& Hagen 2009, p. 205). From the data analysis, there were twelve occurrences of could which functioned to show past ability. An example of this function was presented in [15].

Table 5: The Occurrences of Could

\begin{tabular}{|c|c|}
\hline Function & Occurrences \\
\hline past ability & 12 \\
\hline polite request & 0 \\
\hline Suggestion & 2 \\
\hline 50\% or less certainty & 5 \\
\hline Impossibility & 2 \\
\hline TOTAL & $\mathbf{2 1}$ \\
\hline
\end{tabular}

[15] She ran for a mayoral position in a small town in the West Bank of Palestine and successfully proved she could lead about 8,000 people for two months. (November 1, 2012)

Sentence [15] explained that Bashaer Othman, whom 'she' in the example referred to, had been able to lead about 8000 people for two months.
Azar and Hagen also state that could can also be used to express polite request in the present or future time (2009, p. 205). However, as it was mentioned earlier, in the data there was no polite request shown. Could also shows suggestion in the form of affirmative sentences, less than $50 \%$ certainty, and impossibility in the negative form (Azar \& Hagen, 2009, p. 205). 
There were two occurrences of could showing suggestion. The first could found in sentence [16]was a suggestion to make a better contact among nations.

[16] Better contact among nations could have been enhanced to prevent hunger and other problems, which otherwise couldn't have been prevented. (November 2, 2012)

In that sentence the commentator gave suggestion to other parties about how to handle or solve some problems rising at that moment.

The third function of could implied $50 \%$ or less certainty. There were five occurrences. Sentence [17], related to the international politic issue, illustrated this function.

[17] In fact, our close and friendly relations with nearby Australia could be the envy of many. (November 10, 2012)

The commentator was giving an opinion that there was a possibility where the close and friendly relationship with Australia became the envy of many other countries. In this sentence, he expressed his prediction but he also felt not really sure about it by using could as the modal in his comment.
The last function of could was showing impossibility. It takes place only in the negative sentence (Azar \& Hagen, 2009, p. 205). This function was illustrated by the second couldin [16]. Could appeared in negative form. Thus, it showed impossibility.

\section{Be Able to}

Be able to is meant to show ability (Azar \& Hagen, 2009, p. 205). There were four occurrences of be able to, and all of them performed the same function. In sentence [18], the commentator expected that Obama had the power or skill needed (i.e. ability) to fix US economy and other problems in the US. Therefore, be able to in that sentence showed the ability of Obama.

[18] With this new term, we hope he will be able to fix the US economy and the world and, more importantly, fight poverty and bring peace and security. (November 9, 2012)

\section{Would}

Text Your Say of The Jakarta Post issued in November 2012 had twenty occurrences of would showing various functions. The functions and the number of would occurrences was shown in Table 6 . However, there were some functions which did not appear in the data.

Table 6: The Occurrences of Would

\begin{tabular}{|c|c|}
\hline Function & Occurrences \\
\hline polite want & 2 \\
\hline repeated action in the past & 0 \\
\hline unfulfilled wish & 9 \\
\hline Preference & 0 \\
\hline polite request & 0 \\
\hline fulfilled future condition & 7 \\
\hline Willingness & 2 \\
\hline TOTAL & $\mathbf{2 0}$ \\
\hline
\end{tabular}


The first function shown was polite want. There were two occurrences showing polite want. In sentence [19], the commentator inserted would like and it was obvious to have this function. Would can show a polite form of "want" by adding "like" after would (Azar \& Hagen, 2009, p. 205).

[19] First of all, I'd like to congratulate President Obama on his reelection. (November 9, 2012)

Azar and Hagen (2009) also state that would is possible to show repeated action in the past. However, there was not any would showing repeated action in the past. The same thing occurred with preference and polite request as the functions of would. Would plus rather will show preference and polite request (Azar \& Hagen, 2009, p. 205). However, there was not any would functioning as preference and polite request in the data.

Azar and Hagen (2009, p. 205) also propose expressing unfulfilled wish as one of the functions of would. What Azar and Hagen (2009) call as unfulfilled wish is the same as what Leech and Svartvik (1994) call as a hypothesis. In the data, there were nine occurrences of would. Sentence [20] was one of the comments showing this function.

[20] This revelation would have been effective and useful had it been launched before a building in the corrupt project collapsed, embarrassing the whole nation to the core. (November 7, 2012)

That example explained that the revelation was not really useful and effective because the revelation was late. Therefore, would in the comment was functioning as unfulfilled wish or hypothesis.

Leech and Svartvik (1994) also add that would can express fulfilled future condition in the past (p. 79). It means that the future is seen from a point of view in the past. From all the comments being analyzed, there were seven occurrences of would which were implying fulfilled future condition in the past. In showing fulfilled future condition, Leech and Svartvik (1994) explain that it is possible to put the future constructions into the past tense (p. 79). Using that discussion, in sentence [21], the commentator put the future construction into the past tense.

[21] Agents and immigration would be a good place to stop the rot. (November 16, 2012)

Agents and immigration were really a good place to stop the rot. It showed that would functioned to express a fulfilled future condition in the past.

The last function of would expressed by the commentator was willingness. There were two occurrences. Sentence [22] was an example of this function.

[22] These police officers have gang-raped before and were so sure that no Indonesian maid would report them. (November 16, 2012)

It showed the willingness of Indonesian maid to report the incidents although there was no Indonesian maid was willing to report. However, the word would in the sentence contained and explained the willingness of a person to do something. Therefore, that sentence exemplified the use of would to show willingness.

Table 7 summarized the occurrences of each modal and its corresponding percentage. From Table 7 it was seen that will was the most commonly used modal because it appeared 67 times or equaled $29.78 \%$ of the use of modals. As it was stated before, ought to, have got to, be going to, used to, and shall were not used by the commentators. 
Table 7: The Frequency of Modals' Occurrences

\begin{tabular}{|c|c|c|}
\hline Modals & Occurrences & Percentage (\%) \\
\hline May & 1 & 0.44 \\
\hline Might & 4 & 1.78 \\
\hline Should & 30 & 13.33 \\
\hline Had better & 1 & 0.44 \\
\hline Be supposed to & 1 & 0.44 \\
\hline Must & 20 & 8.89 \\
\hline Have to & 16 & 7.12 \\
\hline Will & 67 & 29.78 \\
\hline Can & 40 & 17.78 \\
\hline Could & 21 & 9.33 \\
\hline Be able to & 4 & 1.78 \\
\hline Would & 20 & 8.89 \\
\hline Total & $\mathbf{2 2 5}$ & $\mathbf{1 0 0}$ \\
\hline
\end{tabular}

There were some possibilities about modals which could be learned from the findings. Will and can were the modals which had the biggest percentage. Will had 29.78\%; can had $17.78 \%$. The possibilities of this result are (1) will and can were the modals which people were most accustomed to, and (2) these two modals had the functions which the commentators wanted to express.
There were 25 functions of the modals which are proposed by Azar and Hagen (2009) andLeech and Svartvik (1994), but there were several functions which were not used by the commentators. Table 8 summarized the function of the modals found and their corresponding percentage. Based on the table, it could be concluded that there were no one requesting and giving permission in the comments.

Table 8: The Functions Performed by Modals

\begin{tabular}{|c|c|c|c|c|}
\hline No & Functions & Modals & \multicolumn{2}{|c|}{ Occurrences } \\
\hline \multirow{5}{*}{1} & \multirow{5}{*}{ Polite request } & May & 0 & \multirow{5}{*}{0} \\
\hline & & Might & 0 & \\
\hline & & Will & 0 & \\
\hline & & Could & 0 & \\
\hline & & Would & 0 & \\
\hline 2 & Informal polite request & Can & 0 & 0 \\
\hline 3 & Formal permission & May & 0 & 0 \\
\hline 4 & Informal permission & Can & 0 & 0 \\
\hline
\end{tabular}




\begin{tabular}{|c|c|c|c|c|}
\hline \multirow{3}{*}{5} & \multirow{3}{*}{$50 \%$ or less certainty } & May & 1 & \multirow{3}{*}{10} \\
\hline & & Might & 4 & \\
\hline & & Could & 5 & \\
\hline 6 & $90 \%$ certainty & Should & 4 & 4 \\
\hline 7 & $95 \%$ certainty & Must & 5 & 5 \\
\hline 8 & $100 \%$ certainty & Will & 49 & 49 \\
\hline \multirow{2}{*}{9} & \multirow{2}{*}{ Ability/possibility } & Can & 33 & \multirow[b]{2}{*}{37} \\
\hline & & Be able to & 4 & \\
\hline 10 & Past ability & Could & 12 & 12 \\
\hline \multirow{2}{*}{11} & \multirow{2}{*}{ Impossibility (negative) } & Can & 7 & \multirow[b]{2}{*}{9} \\
\hline & & Could & 2 & \\
\hline 12 & Necessity & Have to & 16 & 16 \\
\hline 13 & Strong necessity & Must & 14 & 14 \\
\hline 14 & Lack of necessity negative) & Have to & 0 & 0 \\
\hline \multirow{2}{*}{15} & \multirow{2}{*}{ Advisability } & Should & 26 & \multirow[b]{2}{*}{27} \\
\hline & & Had better & 1 & \\
\hline 16 & Suggestion & Could & 2 & 2 \\
\hline 17 & Prohibition (negative) & Must & 1 & 1 \\
\hline 18 & Expectation & Be supposed to & 1 & 1 \\
\hline 19 & Unfulfilled expectation & Be supposed to & 0 & 0 \\
\hline 20 & Unfulfilled wish/ hypothesis & Would & 9 & 9 \\
\hline \multirow{2}{*}{21} & \multirow{2}{*}{ Willingness } & Will & 18 & \multirow[b]{2}{*}{20} \\
\hline & & Would & 2 & \\
\hline 22 & Preference & Would & 0 & 0 \\
\hline 23 & Repeated action in the past & Would & 0 & 0 \\
\hline 24 & Polite for "want" & Would & 2 & 2 \\
\hline 25 & Fulfilled future condition in the past & Would & 7 & 7 \\
\hline \multicolumn{3}{|c|}{ TOTAL } & 225 & 225 \\
\hline
\end{tabular}

Necessity was shown with some degrees but there was no commentator who implied lack of necessity in his comments. It also happened to the unfulfilled expectation, preference, and repeated action in the past.

The result of the function analysis also revealed that $100 \%$ certainty and ability/possibility were the functions mostly expressed by the commentators. The $100 \%$ certainty was expressed by will, while 33 out of 37 expressions of showing ability/possibility were expressed by can. It showed that people commenting on some issues in Text Your Say often expressed their full certainty of something and ability/possibility.

In addition to the explanation of the use of modals and their functions, some modals were not used by the commentators. They were ought to, have got to, be going to, used to, and shall. The commentators preferred to use should than ought to which conveys the same functions. It also happened with have got to. Instead of using this modal, people chose to use have to. In showing $100 \%$ certainty, 
people also tended to use will than be going to. It showed that people were not familiar with some modals.

\section{CONCLUSIONS}

Based on Azar's and Hagen's explanation and category of the modals (2009), the 225 modals found in the data showed that modals had varying number of occurrences. They also revealed or performed various functions with different number of instances. Will and can were the modals which had the biggest percentage. The possible reasons for this result were (1) will and canwere the modals which people were most accustomed to, and (2) these two modals had the functions which the commentators wanted to express.

The findings also revealed that some modals werenot used by the commentators. They were ought to, have got to, be going to, used to, and shall. The commentators preferred to use should than ought to which conveys the same functions. It also happened with have got to. People chose to use have to rather than have got to. To show $100 \%$ certainty, people also tended to use willthan be going to. It showed that some modals were more familiar than others. Furthermore, not all functions were shown by the commentators. It was discovered from the findings that in commenting on some issues, people never made any polite request, despite its possibility to be expressed through various modals, namely may, might, will, could, and would.

\section{REFERENCES}

Azar, B. S. (1993). Understanding and using English grammar. Jakarta Barat: Binarupa Aksara.

Azar, B. S.,\& Hagen, S. A. (2009). Understanding and using English grammar ( $4^{\text {th }}$ ed.). New York: Pearson Education.

Celce-Murcia, M.,\& Larsen-Freeman, D. (1999). The grammar book: An ESL/ EFL teacher's Course (2 ${ }^{\text {nd }}$ ed.). New York: Heinle \& Heinle Publishers.

Fowler, R. (1986). Linguistic criticism. Oxford: Oxford University Press.

Halliday, M. A. K. (2004). An introduction to functional grammar( $3^{\text {rd }}$ ed.). London: Hodder Education.

Jackson, H. (1990). Grammar and meaning. New York: Longman Inc.

Leech, G., \& Svartvik, J. (1994). A communicative grammar of English ( $2^{\text {nd }}$ ed.). New York: Longman Publishing.

Lehmann, W. P. (1983). Language: An introduction. New York: Random House, Inc.

McManis, C., Stollenwerk, D., \& ZhengSheng, Z. (1987). Language files. Ohio: Advocate Publishing Group.

Palmer, F. R. (1981). Semantics ( $\left.2^{\text {nd }} e d.\right)$. Cambridge: Cambridge University Press.

Wales, H. G. (1989). Language style. New York: Richard D. Irwin Inc. 